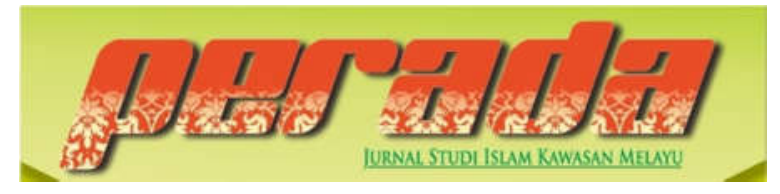

\author{
Perada: Jurnal Studi Islam Kawasan Melayu \\ ISSN 2656-7202 (P) ISSN 2655-6626 (0) \\ Volume 4 Nomor 1, Januari-Juni 2021 \\ DOI: https://doi.org/10.35961/perada.v4i1.292
}

\title{
TARIQ RAMADAN DAN FAHAM BUDAYA ISLAM YANG TOLERAN DAN INKLUSIF
}

\author{
Ahmad Nabil Amir \\ International Institute of Islamic Thought and Civilization (ISTAC) \\ nabiller2002@gmail.com
}

\begin{abstract}
ABSTRAK
Tulisan ini bertujuan mengetengahkan pemikiran Tariq Said Ramadan (lahir 1962), reformis Islam abad ke dua puluh satu, dan menyorot pengaruh intelektual dan idea pembaharuan Islamnya dari sumber-sumber penulisannya yang ekstensif. Kajian membuktikan bahawa Ramadan merupakan antara penganjur Islam moden yang terpenting di abad ke-21. Idealisme pembaharuan ini diketengahkan dalam buku-bukunya seperti What I Believe, Radical Reform, To Be A European Muslim dan Western Muslims and the Future of Islam yang membawa filsafat pemikiran modennya dan tinjauannya tentang Islam dan masyarakat Muslim di Eropah. Pengembangan pengaruh intelektualnya di kalangan Muslim Eropah banyak terkesan oleh karya dan wacana modennya yang berpengaruh tentang semangat inklusivisme dan pluralisme, idea reform, masyarakat sivil, prinsip ijtihad dan pembelaan kaum minoriti. Paul Donnelly dalam The Washington Post mengungkapkannya sebagai "A Muslim Martin Luther" atau "Martin Luther-nya Islam". Kaedah penelitian bersifat kualitatif, berasaskan tinjauan kepustakaan dan analisis kandungan terhadap sumber data secara deskriptif dan historis. Hasil kajian menyimpulkan bahawa Ramadan telah menggerakkan reformasi yang signifikan di dunia Islam dalam menghadapi tantangan moden Barat dan memainkan peran yang instrumental dalam upaya kebangkitan dan nahdah yang mengesankan.
\end{abstract}

This paper aims to reflect the progressive ideal of reform of Tariq Said Ramadan (born 1962), an accomplished Muslim reformist dan leading exponent of modern Islam in 21th century and its instrumental impact based on his extensive philosophical writings. It argued that Ramadan was arguably the most influential modernist and its leading proponent in the modern history of Islam. The paper endeavors to analyze his modern ideal as articulated in his works such as What $I$ Believe, Radical Reform, To Be A European Muslim and Western Muslims and the Future of Islam. Aspiring for meaningful realization of reform and inclusivism, it brought forth his perspective on minority Muslim in Europe and highlights its compelling and dynamic influence in modern intellectual discourse of civil Islam. Paul Donnelly in The Washington Post has rightly acclaimed him as "A Muslim Martin Luther". His profound and discursive thoughts essentially emphasize on radical reform, pluralism and ijtihad (independent thinking), articulating its contextual interpretation and significant meaning. The study is based on qualitative method focusing on descriptive and historical analysis of related works and studies of his principal 
works. The finding shows that Ramadan has brought forth significant reform in the Muslim world that creatively responds to the present challenge of the western world.

Kata Kunci: Tariq Ramadan, Reformer Islam, Martin Luther

\section{PENDAHULUAN}

Tariq Ramadan adalah pemikir Islam moden yang gigih memperjuangkan kebangkitan dan membawa ide pembaharuan di dunia Islam. Pemikirannya yang progresif dan dinamik memberi impak yang signifikan dan menzahirkan pengaruh yang meluas di dunia Islam. Aspirasi pembaharuan dan nilainilai ijtihad yang ideal diangkat dalam karyakaryanya yang penting seperti What I Believe (Apa yang Saya Yakini), Radical Reform: Islamic Etbics and Liberation (Reformasi Radikal: Etika Islami dan Pembebasan), The Arab Awakening: Islam and the New Middle East (Kebangkitan Arab: Islam dan Timur Tengah Baru), The Quest for Meaning: Developing a Philosophy of Pluralism (Pemaknaan Hakiki: Membangunkan Falsafah Kejamakan), Western Muslims and the Future of Islam (Muslim Barat dan Masa Depan Islam) dan lain-lain.

Dalam bukunya 'What I Believe' (diterjemah dan diterbitkan di Italia sebagai Islam e libertá dan Arab sebagai Al Islam walHurreya Qira'a min al-Dakbil Ramadan memaparkan pandangan budaya dan falsafah yang kreatif yang cuba diketengahkannya dalam diskusi pembaharuan dan pemikiran Islam moden. Ini dirangka dalam naratif yang menarik dan penceritaan peribadi yang mendalam tentang dirinya, sebagai pemikir dan ahli teologi Islam dan antara pelopor ideologi modennya yang mendasar di era milenium. Beliau menandaskan:

"I do not represent all Muslims but I belong to the reformist trend. I am to remain faithful to the principles of Islam, on the basis of scriptural sources, while taking into account the evolution of historical and geographical contexts... unlike literalists who merely rely on quoting verses, reformists must take the time to put things in perspective, to contextualize, and to suggest new understandings."1

1 Tariq Ramadan, What I Believe (New York: Oxford University Press, 2010), h. 2.
Sebagai pemikir yang humanis, dan pendukung cita-cita politik dan faham sosial Islam yang ideal, ia telah mencetuskan aspirasi reform yang bersifat perenial dan menyejagat (global) yang digarap secara intens dan dramatis dalam buku-bukunya. Salah satunya adalah What I Believe ini. Dalam buku ini ia menelusuri perjalanan awal kehidupannya, dan menyorot pembawaan modennya sebagai sosok Muslim di Eropah, kareernya sebagai pemikir dan filosof dan intelektual Islam yang kontroversial "controversial intellectual", tentangan dan cabaran intelektual yang dihadapinya, dan melukiskan pengalaman dan aspirasi penting dari projek modernisme Islam yang dikumandangkannya.

Fikrah dasarnya ini diungkapkan dengan jelas dalam pengantarnya: "This book is a work of clarification, a deliberately accessible presentation of the basic ideas I have been defending for more than twenty years...presenting the substance of my thought beyond controversy and polemics." 2 (Buku ini adalah karya penjelasan, penyampaian yang bisa terus diakses tentang ide-ide asas yang telah saya pertahankan sejak dua puluh tahun... menjabarkan isi pokok dari pemikiran saya melangkaui kontroversi dan polemik)

Spencer Dew, dalam Rain Taxi Review of Books menyingkapkan bahawa What I Believe ini menawarkan imbasan yang mudah diakses dan terkadang agak mengharukan ke dalam pemikiran sosok yang penting ini, yang menjadi ikhtisar dari pandangannya tentang kehidupan moden kaum Muslimin Barat. Ia merupakan karya yang padat yang melukiskan dirinya, secara ringkas dan rasional, tentang apa yang ia pertahankan; daripada kritikan dan pertuduhan yang diulang-ulang dan "ditumpukkan di sana sini di internet". Ia membayangkan upaya untuk menangkis serangan dari "beberapa fron" terutamanya propaganda yang digerakkan media-media Barat. Menurutnya "pertamanya, garis keturunanku diserang. Sebagai cucu kepada

2 Ibid. 
pendiri al-Ikhwan al-Muslimin, secara definisi aku adalah merbahaya dan aku tidak harus didengar. Islam, manusia berkata dan masih mengulangi, membenarkan penyamaran (taqiyyah) dan justeru aku mempraktikkannya secara ekstrim; semua yang kedengaran begitu baik kepada khayalak Barat tak lain dari sisi yang dapat disuguhkan daripada agenda yang yang samar yang jauh lebih tersembunyi: aku ingin mengislamkan moderniti, Eropah dan masyarakat Eropah, segenap Barat, dan aku tentunya mempunyai perkaitan dengan kumpulan radikal atau teroris. Tuduhan seperti itu diulangi beratus kali di internet (tanpa sebarang bukti, tentunya) kini memberi kesan pastinya terdapat sedikit kebenaran dalam semua ini. Di mana ditemui asap, pastinya ada api, mereka mengulangi, tanpa cuba untuk mencari apakah dia api itu dan siapakah yang menyalakannya." 3 Inilah yang cuba dijawab dan diteliti dalam tulisan ini untuk melihat kekuatan dan kepentingan fikrah dan hujah balas yang dilontarkannya.

Kaedah penelitian ini bersifat kualitatif, berasaskan tinjauan kepustakaan dan analisis kandungan terhadap sumber data secara deskriptif dan historis. Sumber-sumber data diperoleh daripada bahan-bahan primer dan sekunder yang terkait. Kerangka teoretis ini menjadi landasan inferential untuk dianalisis secara mendalam dan analitik.

\section{RIWAYAT RINGKAS}

Tariq Ramadan adalah putera kepada Said Ramadan dan Wafa al-Bana, yang merupakan puteri tertua kepada Hassan alBanna, pengasas Ikhwan al-Muslimun (yang didirikan pada 1928). Gamal al-Banna, reformis Muslim yang liberal, adalah pamanbesarnya. Ramadan mempelajari falsafah dan kesusasteraan Perancis di peringkat Sarjana dan memperoleh $\mathrm{PhD}$ dalam pengajian Arab dan Islam dari University of Geneva. Beliau menulis disertasi kedoktorannya tentang Friedrich Nietzsche, bertajuk Nietzsche as a Historian of Philosophy [Nietzsche sebagai Filasuf Sejarah]. Ramadan kemudian menyambung kajiannya dalam perundangan Islam di Universiti Al-Azhar. Di Kaherah beliau mendapat pentauliahan daripada ulama al-

\footnotetext{
${ }^{3}$ Ibid, hh. 16-17.
}

Azhar dengan latihan intensif (talaqqi) dalam mendalami teks-teks klasik.

Dilahirkan di Swiss, Geneva pada tahun 1962, Ramadan pernah mengajar di College de Saussure, sekolah tinggi di Geneva, Switzerland dan menjadi pensyarah Agama dan Falsafah di University of Fribourg dari 1996 ke 2003. Pada Oktober 2005 beliau memulakan kareernya di St Antony College, University of Oxford selaku Felo Pelawat. Pada tahun 2005 beliau dilantik sebagai felo penyelidik kanan di Lokahi Foundation. Pada 2007 Ramadan berjaya ditunjuk sebagai profesor dalam pengajian Islam di University of Leiden, tetapi kemudian menolak jabatan itu, kerana alasan-alasan profesional. Beliau juga adalah profesor pelawat tentang Identiti dan Kerakyatan di Erasmus University Rotterdam sehingga Ogos 2009 ketika Perbandaran Rotterdam and Erasmus University menyingkirkannya dari jawatannya sebagai "penasihat integrasi" dan profesor, menyebut bahawa program yang dipengerusikannya tentang Siaran TV Iran, Islam \& Life "tidak selari" dengan tugasnya di Rotterdam. Tariq menyifatkan aksi ini sebagai Islamofobia dan bermotif politik. Bermula September 2009, beliau menyandang Kursi His Highness Hamad Bin Khalifa Al-Thani Chair dalam Pengajian Islam Kontemporari di Universiti Oxford.

Ramadan aktif menyampaikan syarahan tentang isu-isu Islam dan umat Islam, perundangan, etika, teologi, ekologi dan dialog antara agama di rantau Asia, Eropah, dan Amerika. Beliau turut membentuk Mouvement des Musulmans Suisses (Movement of Swiss Muslims - Gerakan Muslim Switzerland), yang terlibat dalam bermacam seminar antara agama. Beliau merupakan penasihat EU (European Union) tentang isu-isu agama dan dirujuk bagi usulnya oleh EU tentang suruhanjaya tentang "Islam dan Sekularisme”. Pada September 2005 beliau diundang untuk menyertai pasukan kerja oleh pemerintah United Kingdom. Beliau juga adalah Presiden Euro-Muslim Network (Jaringan Muslim Eropah), tangki-pemikir yang beroperasi di Brussels. Sepanjang kareernya Ramadan telah meraih pengalaman yang bermakna melalui pembabitannya dalam gerakan dan jaringan aktivisme Islam yang meluas. Menurutnya: 
"I began to get more specifically involved with the issue of Islam and Muslims in the world, and particularly in the West, in the late 1980s and early 1990s. Before that and for many years since the age of eighteen - I had traveled extensively in the Third World from South America to India and through many countries on the African continent." 4

[saya mula terlibat dengan lebih spesifik dalam isu Islam dan umat Islam di dunia, dan terutamanya di Barat, pada akhir 1980 an dan awal 1990 an. Sebelum itu dan selama bertahun-tahun - sejak usia lapan belas - saya telah menjelajah dengan meluas di Dunia Ketiga dari Amerika Selatan ke India dan melalui banyak negara di benua Afrika]

Pengalaman ini membuatkannya lebih insaf dan tawaduk dan punya ketundukan intelek: "Saya telah bekerja selama dua puluh lima tahun dalam bidang perundangan dan sekarang saya telah capai apa yang saya kejar, iaitu terapan etika Islam dan saya juga menangani permasalahan umat Islam di Barat. Tetapi terdapat dimensi lain yang juga mustahak. Dan lantaran banyak kembara dan belayar dan menemui manusia dari pelbagai horizon ia membuatkan anda lebih tawadu' dan sedia untuk mendengar." 5 Menggariskan falsafah dan pandangan hidupnya yang meluas ini beliau merumuskan ikhtisarnya dalam bukunya The Quest for Meaning: "My philosophy is travel, and pluralism is my destination. Humility is my table, respect is my garment, empathy is my food, and curiosity is my drink. As for loves, it has a thousand names and is by

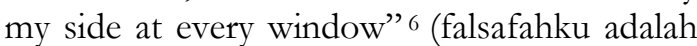
petualangan, dan pluralisme adalah destinasiku. Kerendahan hati adalah mejaku, penghormatan adalah pakaianku, empati

${ }^{4}$ Tariq Ramadan, What I Believe, h. 8.

5 Ahmad Fuad Rahmat. "An Interview with Tariq Ramadan." (Temubual dengan Tariq Ramadan). http://irfront.net/post/interviews/aninterview-with-tariq-ramadan/, diakses August 3, 2012.

6 Tariq Ramadan. The Quest for Meaning: Developing a Philosophy of Pluralism (Penguin Global: 2012), h. xii. makananku, dan rasa ingin tahu minumanku. Adapun tentang cinta, ia punyai ribuan nama dan berada di sampingku di setiap jendela),

Ramadan telah diberikan liputan global dan temuramah yang meluas dan telah menghasilkan lebih 100 pita rakaman yang salinannya dijual berpuluh ribu setiap tahun. Beliau telah mendirikan rumah tangga dengan seorang Muslimah (mualaf) Perancis dan memperoleh empat orang cahaya mata. Sehingga 2009, Tariq Ramadan adalah persona non grata di Tunisia, Mesir, Arab Saudi, Libya atau Syria kerana "kritikannya terhadap regim yang tidak demokratik ini yang menafikan hak asasi manusia yang asasi."

Pada 2004, beliau dihalang dari memasuki Amerika Syarikat oleh pentadbiran Bush, dan, sekalipun dengan dua rayuan, beliau disekat dari negara tersebut sehinggalah musim semi 2010, ketika Setiausaha Negara Hillary Clinton akhirnya mencabut larangan itu. Mutakhir, Ramadan ditunjuk sebagai profesor Pengajian Islam Kontemporari di Universiti Oxford (Institut Oriental, Kolej St Antony) di samping mengajar di Fakulti Teologi, Oxford. Selain itu beliau juga menjawat profesor pelawat di Fakulti Pengajian Islam, Qatar dan Universiti Malaysia Perlis; Felo Penyelidik Kanan di Doshisha University (Kyoto, Japan) dan Pengasas dan Pengarah Pusat Penyelidikan Perundangan dan Etika Islam (Research Centre of Islamic Legislation and Ethics (CILE) di Doha, Qatar. Terkini pada 2 Februari 2018 beliau ditahan di Perancis di penjara terbesar di Eropah, FleuryMerogis atas tuduhan liar pemerkosaan dua orang wanita, pada 2009 dan 2012, bernama Christelle dan aktivis feminis, Henda Ayari. Setelah sembilan bulan ditahan tanpa diadili beliau dibebaskan usai rayuannya yang keempat dengan wang ikat jamin sebanyak 300,000 euro (MYR 1.42 juta) setelah menyerahkan pasport Swissnya.

\section{KARYA DAN PEMIKIRAN}

Tariq Ramadan terkenal dengan penulisannya yang kritis. Ini dilakarkan dalam karya-karyanya yang prolifik seperti The Quest for Meaning: Developing a Philosophy of Pluralism; Islam, the West and the Challenges of Modernity; In the Footsteps of the Prophet: Lessons from the Life of Muhammad (saw); The Messenger: The Meanings of the Life of Mubammad (saw) dan lain-lainnya. 
Buku-buku ini menganalisis dengan mendalam tentang hubungan Islam dan Barat, posisi Muslim di Eropah, kebangkitan musim semiArab, reformasi pemikiran, ijtihad, rekonstruksi fatwa (fatāwa $)$, pembaharuan fiqh dan syariat dan sirah Rasulullah (saw) dan pemahaman moral dan etikanya. Ia membawa gagasan penting yang dilakarkan dengan berkesan yang menggarap tema-tema yang krusial seperti isu-isu wanita, sosio politik, media, identiti Muslim di Eropah, etika, tradisi agama, reformasi pemikiran, akar kebudayaan Eropah, pandangan dunia Barat, dan sebagainya. Pandangan Islam yang progresif yang diperjuangkan dan dipertahankannya dengan konsisten diperlihatkan dalam bukunya 'Radical Reform: Islamic Ethics and Liberation' yang mengalamatkan masyarakat dan komuniti Islam di mana-mana dengan seruan yang berani kepada reformasi radikal. Beliau mencabar mereka yang berhujah secara defensif bahawa reformasi adalah merbahaya dan penyimpangan luar, dan pengkhianatan kepada agama. Reformasi yang sebenar, katanya, sentiasa berakar dalam sumber tekstual Islam, tujuan spiritual dan tradisi intelektualnya. Tetapi gerakan reformis yang berasaskan kepada pembacaan yang diperbaharui terhadap sumber tekstual dengan menggunakan manhaj dan kategori tradisional hanya berhasil mencapai respon yang adaptif terhadap krisis yang mendepani dunia global. Pembacaan tersebut, Ramadan berhujah, telah mencapai batas daripada kegunaannya.

Menurutnya: "Kita harus
membezakan autoriti daripada pilar yang fundamental, qat'iy, aqidah, ibadab dan larangan yang tidak dipertikaikan dengan autoriti yang tertinggi. Kemudian, di sana terdapat masalih, yang perlukan konsensus, syura, yang merupakan cabaran dan model semasa dalam ruang awam. Apa jua yang berada dalam ruang awam harus ditangani dengan posisi etika". ${ }^{7}$

Ramadan tampil sebagai satu suara yang terkehadapan daripada para reformis Islam di Barat, yang terkenal kerana saranannya kepada umat Islam untuk terlibat sepenuhnya dalam kehidupan sivil dalam

7 Tariq Ramadan, "Islam, Democracy \& Human Rights: The Awakening of the Muslim World" Penang in Asia Lecture III. Pinang Ballroom, Traders Hotel, Penang, 17 July 2012. masyarakat Barat di mana mereka tinggal. Ramadan menyeru kepada reformasi radikal yang melangkaui penyesuaian bagi membayangkan solusi yang berani dan kreatif untuk mentransformasi masyarakat kita di masa ini dan di masa depan. Pendekatan yang baru ini mempertanyakan sumber-sumber sejarah yang tertegak, kategori, objektifobjektif tertinggi, sarana, dan metodologi hukum dan figh Islam, dan autoriti yang geografi dari pengetahuan tradisional ini telah berikan kepada ulama tekstual. Beliau mengusulkan geografi yang baru yang mendefinisikan semula sumber dan tujuan spiritual dan etika hukum yang menciptakan ruang bagi autoriti ulama dari sains sosial dan tabii. Ini akan menyiapkan reformasi transformatif ini dengan pengetahuan spiritual, etika, sains dan saintifik yang perlu untuk menangani cabaran kontemporer.

Ramadan berhujah bahawa reformasi radikal menuntut tidak hanya sumbangan ulama yang setara dalam kedua-duanya teks dan konteks tetapi juga keterlibatan yang kritis dan imaginasi yang kreatif daripada para intelektual dan kelompok massa Muslim. Saranan bagi reformasi radikal ini secara dramatik mengalihkan pusat graviti kekuasaan. Ia melakukan sintesis dari beberapa pendekatan klasik usul al-figh, antara manhaj istintaji (deduktif) Imam asy-Syafici, manhaj istiqra' (induktif) mazhab Hanafi, dan mazhab maqasidi (matlamat akhir syariat), dengan konteks sebagai sumber hukum dan penerapan etika Islami. Dalam hal ini, ia tampil membawa etika Islam sebagai penentu dalam menanggapi tradisi, kebudayaan dan kesenian, dengan nilai kebebasan dan etika yang universal.

Bagi golongan literalis, pengikutan kepada Rasulullah s.a.w., para sahabat r.anhum dan generasi terawal (salafus soleh) pada asasnya dengan mencontohi akhlak mereka dan menghidupkan semula amalan-amalan lampau. Kekeliruan berlaku antara prinsip dan model, antara hukum dan bentuknya, dan ini menyebabkan kekakuan dan sikap yang sangat eksklusif. ${ }^{8}$

Idea kebebasan dan etika (Islamic Ethics and Liberation) yang substantif ini menekankan

8 Tariq Ramadan, Radical Reform: Islamic Ethics and Liberation (New York: Oxford University Press, 2009). 
keperluan untuk meraih liberasi etika, sebagai substansi dan prinsip yang fundamental dan aspirasi pokok daripada buku ini: "[ia] adalah etika dan kebebasan (liberasi), dan akibatnya terhasil etika liberasi. Kita harus membebaskan pemikiran Muslim dari keasyikan dengan kekangan dan undang-undang dan melupakan jalan dan maqasid. Ini sebenarnya proses pembebasan, dan bagi saya inilah Islam: kebebasan dari belenggu keegoan, dan dalam kes ini membebaskan diri kita dari pemahaman yang salah tentang agama. Kerana etika pada asasnya yang fundamental adalah mempersoalkan tujuan, sasaran dan matlamat, kita harus berpatah balik pada dasar undangundang dan bertanya mengapa. Maka kita harus berbalik kepada falsafah undang-undang, raison d'etre nya, dan poin di sebalik apa yang dituntut kita penuhi. Ia tidak mudah, ia menuntut perjuangan dan ia perlukan keberanian intelek." 9

Dalam bukunya 'The Quest for Meaning: Developing a Philosophy of Pluralism' (Pemaknaan Hakiki) Ramadan mengorak jalan untuk mencari kebenaran yang mendalam yang mengikat kita bersama. Dalam dunia yang penuh dengan pergeseran pandangan dan kepercayaan, bagaimana kita dapat menemui kedamaian dalam kemanusiaan yang dikongsi bersama? Ramadan meneroka idea-idea universal seperti cinta, hormat, kebenaran dan toleransi, dan menyelidik persoalan seperti bagaimana lelaki dan wanita berhubung kepada satu sama lain? Apakah sifat yang sebenar dari persamaan? Apakah 'peradaban' sebenarnya bermaksud? Dalam melakukannya, beliau membuka fikiran kita kepada pandangan yang baru tentang kemanusiaan. Sama ada kita adalah Kristian atau Buddha, Yahudi atau Islam, sekularis atau mukmin, beliau memperlihatkan bahawa semua tradisi pemikiran berpunca dari tempat yang sama, dan menunjuki kita untuk menyingkirkan apa yang memecahbelahkan kita dan menemui keindahan dari apa yang dipunyai bersama.

Dalam era pencarian makna ini, Ramadan menekankan pertimbangan terhadap prinsip akhlak yang mengakari kepelbagaian dan persekitaran itu sendiri, di mana: "Tugas kita, akhirnya, adalah untuk menimbangkan

9 Ahmad Fuad Rahmat. An Interview with Tariq Ramadan, August 3, 2012. prinsip akhlak dan keupayaan teknikal yang terjangkau untuk kita pada hari ini, tanpa sejenak pun melupakan prinsip akhlak yang mengakari kepelbagaian dan persekitaran itu sendiri. Tugas kita adalah untuk menyiapkan kemodenan dengan jiwa, untuk menghidupkan semula daya kreativiti spirituil dan kemanusiaan."10 Menurutnya;

The earliest African and Asian traditions as well as Hinduism, Buddhism then monotheisms, explicitly or implicitly recognise the necessity of other ways: Either because they state that there are several ways of leading to the truth or because that presence influences and shapes my own way of conceiving my own relationship to my truth. Pluralism is here a condition of humility and a protection against potential excess. ${ }^{11}$

Prinsip ini pada asasnya telah dipertahankan oleh Hamka dalam kitabnya Tafsir al-Azhar, terkait dengan tafsirannya pada ayat 69 surat al-Mâidah, yang menganjurkan dasar keterbukaan dan paham toleransi terhadap pengikut agama lain: "Inilah salah satu ayat yang mengandung toleransi besar dalam Islam. Terdapatlah di sini bahwa Islam membuka dada yang lapang bagi sekalian orang yang ingin mendekati Tuhan dengan penuh iman dan amal shalih." 12 Dan dalam mengaitkan keterangan ini dengan ayat 62 surat al-Baqarah, Hamka mengungkapkan: "Inilah janjian yang adil dari Allah kepada seluruh manusia, tidak pandang dalam agama yang mana mereka hidup, atau merk apa yang diletakkan kepada diri mereka, namun mereka masing-masing akan mendapat ganjaran atau pahala di sisi Tuhan, sepadan dengan iman dan amal shalih yang telah mereka kerjakan.” 13

10 Tariq Ramadan. "Strength in Pluralism." (Kekuatan dalam Pluralisme). Gulf News. http://gulfnews.com/opinion/thinkers/strengthin-pluralism, diakses July 23, 2012.

Tolerance."

11 Tariq Ramadan. "Respect Beyond

http://tariqramadan.com/english/respect-beyondtolerance/diakses September 17, 2013.

${ }^{12}$ Hamka. Tafsir al-Azhar, 10 jil (Singapura: Pustaka Nasional, 1982).

13 Ibid. 
Dalam The Quest for Meaning, Ramadan memberikan analogi tentang melihat laut dari jendela, dan keperluan untuk melihat laut dan hakikatnya yang sebenar, dari sekadar hanya melihat jendela. Menurutnya: "Terdapat intuisi Bergsonian ini bahawa wujud banyak jalan untuk mengetahui sesuatu. Satu ialah melalui objek itu sendiri dan yang lain adalah menerusi pandangan yang berbeza dalam lingkungan sekitarnya. Jadi kita harus menggabungkan kefahaman intelek dan intuitif terhadap sesuatu. Justeru untuk mengislamkannya tidak dapat dimengerti kewajarannya. Tetapi untuk menetapkan pusat, untuk mempunyai empati dan kesantunan intelek - semua dimensi ini adalah penting dalam menentukan bagaimana kita melihat kebenaran." 14

Visinya adalah terhadap masa depan di mana pluralisme yang diyakini dan dikongsi bersama menjadi suatu realiti akhirnya, di mana: "Ini tidak bermaksud untuk menghapus rasa kebenaran yang anda yakini tetapi untuk menghargai dan meraikan kenyataan bahawa kita hidup dalam dunia di mana kita perlu tangani pluralisme. Ia adalah kenyataan..masyarakat yang pluralistik. Justeru mereka yang akan melonjak dan menjadi penting di negara ini adalah kalangan yang akan mempersoalkan faham sekterianisme melalui tekanan terhadap nilai bersama dan kefahaman sejagat." 15

The Quest for Meaning menggulirkan falsafahnya yang mendalam tentang idea pluralisme dan aspirasi pemikirannya yang kompleks dan mencapah yang digarap dan dirumuskan dengan berkesan dalam karya ini: "Ia (The Quest for Meaning) adalah rekonsiliasi dengan falsafah dan sajak pada masa yang sama. Ia sesungguhnya menyingkap siapa saya sebenarnya. Ia malah merupakan salah satu dari karya saya yang terbaik. Ia tidak sesungguhnya difahami dengan hakiki oleh umat Islam dan bukan Islam. Malah penerbitnya tidak begitu terangsang dengannya. Tetapi ia adalah buku yang penting kepada saya kerana ia menterjemahkan perjalanan dan pemahaman saya sendiri. Ia

\footnotetext{
14 Ahmad Fuad Rahmat. An Interview with

Tariq Ramadan, August 3, 2012.

15 Ibid.
}

adalah falsafah saya tentang pluralisme, bagaimana saya berfikir tentang "yang lain"." 16

Dalam bukunya "The Arab Awakening: Islam and the New Moddle (Islam dan Kebangkitan Arab), Ramadan meneroka peluang dan cabaran yang menghadap sepanjang Afrika Utara dan Timur Tengah, sebagaimana mereka mengharapkan untuk mencipta masyarakat baru yang lebih terbuka. Beliau bertanya: dapatkah negara-negara Islam mempertautkan Islam, pluralisme dan demokrasi tanpa mengkhianati identiti mereka? Adakah dunia Arab akan mampu untuk mengklaim semula memorinya untuk menemukan kembali pendidikan, hak wanita, keadilan sosial, pertumbuhan ekonomi dan memerangi rasuah? Dapatkah kebebasan ini dibayangkan dengan Islam, dirasai tidak sebagai kekangan, tetapi sebagai kekayaan etika dan budaya?

Berhujah bahawa perdebatan tidak boleh disusutkan kepada konfrontasi antara dua pendekatan - moden dan sekular vs tradisional dan Islamik - Ramadan memperlihatkan bahwa tidak hanya kedua jalan ini dalam krisis, tetapi sebaliknya dunia Arab mempunyai peluang yang historik: untuk berhenti menyalahkan Barat, untuk membuang status mangsanya, dan untuk mencipta dinamik baru yang sebenar. Ramadan menawarkan cabaran kepada Timur Tengah: apakah legasi berpanjangan yang kalian akan hasilkan, dari detik Musim Semi Arab yang historik? 17

Dalam menguraikan rangka besar buku ini beliau mengupas dengan lanjut: "Dalam buku saya yang mutakhir, The Arab Awakening (Kebangkitan Arab) saya kupas tentang kenyataan bahawa kita harus berganjak dari hal ini. Semua ideologi kontemporer dari politik Islam telah bersandar kepada negara bangsa. Negara bangsa nyata bermasalah tetapi saya tidak pasti jika kita mempunyai model politik alternatif. Yang meruntuhkan negara bangsa utamanya adalah tiga perkara: ekonomi global, teknologi komunikasi global dan budaya global. Dan di sinilah di mana kita kesasar dalam proses. Apakah yang dapat 
membekalkan kita dengan rasa terhitung dan dipunyai dalam politik yang melintang? Akhirnya, tanpa suatu alternatif kita tersadai dengan populisme atas nama identiti yang sangat sempit." 18

Baginya, kebangkitan bukan hanya tentang alasan politik tetapi juga tentang sosio ekonomi. Ia bukan gambaran yang tepat jika dilihat hanya dari sudut geo politik belaka. Ia harus dilihat dari parameter yang strategik dan luas, ini termasuk jaminan prinsip demokrasi, autonomi ekonomi, kebebasan, keadilan sosial, negara hukum, kerakyatan yang setara, hak mengundi, pemisahan kuasa, struktur kuasa yang teratur dalam negara. Baginya, etika harus menjadi model yang menentukan sebagaimana ditetapkan oleh tradisi Islam, dan umat Islam harus menghormati prinsip, merangka model yang selaras dengan realiti negara, naratif, sejarah, budaya, dan kerakyatan mereka.

Dalam bukunya In the Footsteps of the Prophet: Lessons from the Life of Muhammad (saw) Jejak-jejak kehidupan Nabi (saw): pengajaran dari sirab Rasulullab (saw)] Ramadan menimbangkan cara di mana perkataan, perbuatan, dan ajaran Nabi (saw) dapat memandu kita di dunia moden. Kehidupan Nabi (saw), terhadap siapa Jibrail menurunkan wahyu al-Qur'an, telah memberikan inspirasi kepada umat Islam selama berabad.

Diselangi dengan renungan kerohanian dan falsafah, biografi yang mendalam dan mempesonakan ini menunjukkan bagaimana pesan Nabi (saw) dapat digunakan untuk menangani sebahagian dari isu-isu yang paling kontroversil hari ini - dari pelayanan terhadap orang miskin dan peranan wanita kepada tafsiran tentang jihad dan hubungan dengan agama lain. Ia menawarkan umat Islam pemahaman yang baru tentang kehidupan Nabi (saw) dan memperkenalkan bukan-Islam tidak hanya dengan kisah Nabi (saw), tetapi kepada kekayaan spiritual dan etika Islam. ${ }^{19}$ Buku ini diilhamkan dari peranannya sebagai penyampai sebuah filem yang berjudul "In the Footsteps of the Prophet Muhammad (saw)" untuk sebuah stesyen televisyen Inggeris.

18 Ahmad Fuad Rahmat. An Interview with Tariq Ramadan, August 3, 2012.

19 Tariq Ramadan, In the Footsteps of the Prophet: Lessons from the Life of Muhammad (New York: Oxford University Press, 2007).
"Namun, karena berbagai pertimbangan politis (dua pemerintahan Arab mencekal saya masuk wilayah mereka) projek tersebut tidak berlanjut. Lalu, saya memutuskan untuk melakukan sesuatu yang sepenuhnya berbeda, yaitu menulis biografi Nabi Muhammad (saw) sebagai upaya menjelaskan ajaran-ajaran spiritual Nabi terakhir ini." 20

Dalam tulisannya 'Islam' (A Pelican

Introduction) Ramadan menyuguhkan pengenalan yang mendasar tentang Islam yang menguraikan kefahaman dan pertanyaan asas seputar: Apakah Islam? Apakah perkataan seperti 'Allah', 'Sharia', 'Jihad', dan 'Kafir' sebenarnya bermaksud?

\section{SOSOK ISLAM MODEN}

Terkenal sebagai sosok modernis dan aktivis Islam yang moderat, Ramadan telah menjadi jurucakap dunia Islam yang penting dalam membela dan mempertahankannya daripada serangan propaganda Barat dan kekeliruan dan prasangka yang disogok tentang Islam. Beliau mempunyai jaringan pengikut yang besar di kalangan anak-anak muda Islam di Eropah dan Muslim di Amerika yang terkesan dengan usaha pembaharuan yang radikal yang dicetuskan.

Sumbangannya yang penting kepada kebangkitan ini dilukiskan dalam pengenalan buku Western Muslims and the Future of Islam yang memperkenalkan tentang usaha radikal dan pengaruh masif Ramadan dalam harakat pembaharuan: "With this ambitious volume, Tariq Ramadan firmly establishes himself as one of Europe's leading thinkers and one of Islam's most innovative and important voices" ${ }^{21}$ [dengan jilid yang sangat berambisi ini, Tariq Ramadan dengan tuntas menegaskan dirinya sebagai salah seorang pemikir Eropah yang terkemuka dan salah satu sosok dan suara Islam yang terpenting dan paling inovatif]

Ini turut diungkap oleh John L Esposito dalam ulasannya terhadap karyanya What I Believe yang menyorotnya sebagai intelektual -aktivis yang terkemuka di Eropah

20 Tariq Ramadan, Mubammad (saw) Rasul Zaman Kita. Terj. R. Cecep Lukman Yasin (Jakarta: Serambi, 2007).

21 Tariq Ramadan, Western Muslims and the Future of Islam (New York: Oxford University Press, 2004). 
dan Amerika - yang mewakili angkatan baru dari pembaharu Islam. Pengaruhnya yang signifikan ini dilihat dari sosoknya yang menginspirasikan, sebagai fenomena global (global phenomenon). Ia tampil sebagai satu suara yang terdepan dari reformis Islam, yang membentuk aspirasi kebebasan yang meluas dan mengesankan, dan sebagai salah seorang sarjana dan cendekiawan Islam yang paling menonjol yang berada di garis depan dalam memerangi kaum literalis. Keyakinannya berteraskan manhaj yang integratif, yang menyatukan pendekatan teologi yang bertenaga, berasaskan nilai dengan pemahaman spiritual yang realistik tentang permasalahan semasa, sebagai resep yang penting bagi pembaharuan yang sebenar, "dan penekanannya bahawa sebagaimana dunia terus berubah, terdapat keperluan bagi pandangan kedua terhadap al-Quran dan teksteks Islam yang lain adalah konsisten dengan semangat islah dan tajdid. Seruannya kepada pembacaan semula terhadap teks-teks Islam ini lantaran banyak kekeliruan di dalam komuniti Islam, sedikit sebanyak menyamai klaim Luther untuk kembali kepada yang dikatakan "teks asli", yang bebas daripada banyak salahtanggapannya yang terkumpul."

\section{REFORMASI RADIKAL}

Dalam bukunya Radical Reform: Islamic Ethics and Liberation Ramadan mengungkapkan tentang gagasan pembaharuan agama (tajdid addin) yang signifikan yang menuntut pembacaan semula yang kritis terhadap teks dan pemahaman kondisi (figh al-bi'ah) yang ramah lingkungan dan meraikan konteks. Pemahaman yang prinsipal ini didasarkan dari takrifnya yang meluas tentang tajdid "... a renewal of the reading, understanding, and, consequently, implementations of texts in light of the various historicultural contexts in which Muslim communities or societies exist." 22

Tinjauan ini turut dilontarkan dengan berkesan dalam perbincangannya tentang model negara Madinah sebagai struktur politik yang bersifat relatif dari realisasi sejarahnya. Menurutnya prinsip tidak dapat berubah, mutlak, dan kekal, tetapi pelaksanaannya dalam waktu ini atau dalam sejarah - model

22 Tariq Ramadan, Radical Reform: Islamic Ethics and Liberation, h. 13. sejarah - adalah relatif, bertukar dan terus menerus berubah. Lantaran itu, prinsip keadilan, kesetaraan, hak asasi dan persaudaraan bangsa manusia yang memandu Nabi (saw) Islam sesungguhnya kekal sebagai rujukan yang melangkaui sejarah, tetapi model kota Madinah yang diasaskan oleh Nabi Muhammad (saw) pada kurun ketujuh adalah realisasi historis yang terkait dengan realiti dan keperluan pada waktunya.

Umat Islam seyogianya, dalam putaran sejarah, cuba untuk terus berpaut pada prinsipprinsip tersebut dan berusaha untuk melaksanakannya sebaik mungkin berdasar kepada keperluan zaman mereka tetapi mereka tidak boleh hanya meniru, menghasilkan semula, atau menyalin model sejarah yang layak pada suatu masa yang khusus tetapi tidak lagi menjawab keperluan dan tuntutan zaman mereka. ${ }^{23}$

Ia menggariskan prinsip dan manhaj pembaharuan dalam pemahaman teks dari rangka kontekstual yang tidak terikat kepada tren literalis yang baku, di mana ramai Muslim yang terperangkap dalam konsep Negara Madinah atau apa yang diungkapkan dalam bukunya Radical Reform, keasyikan terhadap model berbanding dengan prinsip. Pandangan yang radikal ini menekankan kepada semangat dan idealisme yang dikehendaki oleh teks dan maqasid hukumnya yang ideal: "Ramadan asserted that the essence in being faithful to the Prophet is not in imitating their behaviour, or trying to reproduce their historically dated achievements, but it lies in recapturing their spiritual strength and intellectual energy to achieve the most cogent social model for our time, as they did for theirs. It is not to repeat its form but to grasp its substance, spirit and objectives." 24 (Ramadan menekankan bahawa intisari dari kepatuhan pada Nabi (saw) bukan dalam menuruti semberono tindakan mereka, atau cuba menghasilkan semula pencapaian sejarah mereka yang telah usang, tetapi ia terletak dalam menawan semula kekuatan spiritual dan dinamo intelektual mereka untuk mencapai model sosial yang paling beralasan bagi zaman kita, sebagaimana mereka lakukan

23 Tariq Ramadan, Radical Reform: Islamic Ethics and Liberation, h. 19.

24 Ahmad Farouk Musa, "Radical Reform and Tariq Ramadan”, 23 Ogos, 2010. 
untuk zaman mereka. Ia bukan untuk mengulangi bentuknya tetapi untuk memahami intipati, semangat dan tujuannya)

Pandangannya menzahirkan daya pemahaman yang kritis terhadap teks (nusus) dan menegaskan pembaharuan terhadap prinsip dan metodologi usul dan disiplin teras Islam yang dinamik, "I have repeatedly stated that the awakening of Islamic thought necessarily involves reconciliation with its spiritual dimension on the one hand, and on the other, renewed commitment and rational and critical reading (ijtihād) of the scriptural sources in the field of law and jurisprudence" 25 (saya telah berulang kali tegaskan bahawa kebangkitan pemikiran Islam dengan wajar melibatkan rekonsiliasi dengan dimensi spiritualnya pada satu pihak, dan di pihak lain, komitmen yang diperbaharui dan pembacaan yang rasional dan kritikal (ijtihād) terhadap sumber tekstual dalam bidang fiqh dan jurispruden).

Aspirasi perubahan yang kritis yang diperjuangkannya ini dengan tuntas merumuskan pemikirannya tentang prinsip althawabit dan al-mutaghayyirat dan faham rasionalisme dalam tradisi Islam, di mana Ulama Islam yang besar seperti Muhammad Abduh berhujah bahawa manakala sebahagian aspek dari agama kekal tak berubah terutamanya yang menyentuh ibādah dan aqīdah (kepercayaan); isu-isu tentang tatakelola harus ditangani dengan akal manusia kerana ia jatuh dalam lapangan al-mutaghaiyyirat (yang berubah). Ia adalah agenda reformis Abduh dan rasionalismenya ketika itu, dengan penekanannya terhadap nalar ('aql) dan keadilan Tuhan ('ad), yang tampak seakan ia berupaya melantarkan teologi Islam yang dinamik yang sanggup dengan berhasil menjawab cabaran kemodenan. ${ }^{26}$

\section{PEMBAHARUAN HUKUM DAN IJTIHAD}

Tradisi ilmu dan pemikiran dan ijtihad yang mekar dalam warisan Islam menurut Tariq Ramadan, harus dipugar dan

25 Tariq Ramadan, Radical Reform: Islamic Ethics and Liberation, h. 1.

${ }^{26}$ Ahmad Farouk Musa, "Radical Reform and Tariq Ramadan”, 23 Ogos, 2010. dikembangkan dalam zaman moden bagi menangani cabaran kontemporer. 'Today's Muslims, both in the East and West, urgently need contemporary fiqh, distinguishing what in the texts is immutable and what may be changed." 27 Dalam tulisannya, What I Believe Ramadan menekankan tentang kepentingan ijtihad dalam memahami teks (nusus) dan penyesuaiannya terhadap konteks dan tuntutan maqasid. "Saya percaya kita kini harus kembali kepada sumber dari prinsip fiqh dan usul (usūl al-fiqh) dan menanyakan tentang pengkategorian dan metodologi-nya yang asal. Inilah apa yang saya panggil "reformasi radikal", yang harus membawa kita dari mengikhtiarkan perubahan penyesuaian kepada perubahan transformasi yang kreatif." 28

Kerangka asas dari perubahan yang dicadangkannya dibahagikan kepada dua kategori, adaptation reform (perubahan penyesuaian) dan transformation reform (perubahan transformasi). Ia menekankan tentang tafsiran yang inovatif (innovative interpretation), daya ijtihad yang kritis, dan kefahaman figh yang sistematik dan komprehensif, dan perumusan hukum yang kontemporer bagi mencetuskan transformasi yang kreatif. Ini dirumuskannya di mana "Radical reform is an appeal to reconsider the sources to their necessary reconciliation with the world, its evolution and human knowledge" (Reformasi radikal adalah seruan untuk menimbangkan semula sumber kepada rekonsiliasinya yang wajar dengan dunia, evolusinya dan pengetahuan manusia). Ia membawa konsep dan falsafah pemikiran yang mendalam tentang idealisme perubahan dan keperluan dan nilai ijtihad, di mana dunia terus mara dan bergerak dan fuqaha terus tertinggal di belakang kemajuan yang terus memecut itu yang tampaknya terluput dari mereka. Kerana itu, Ramadan mengusulkan, pendekatan transformatif ketimbang dari pendekatan adaptasi. Perubahan transformasi, menurutnya adalah lebih tepat, di mana ia menambah langkah yang lanjut, dan syarat, kepada keseluruhan proses. Ia bertujuan untuk merubah urutan perkara di atas nama etika

27 Tariq Ramadan, Radical Reform: Islamic Ethics and Liberation, h. 1.

28 Tariq Ramadan, What I Believe, h. 85. 
yang ia cuba untuk berpaut padanya. Dengan perkataan lain, untuk menambah langkah yang lanjut yang berangkat dari teks kepada konteks, untuk bertindak di atas konteks dan memperbaikinya, tanpa sama sekali menerima kekurangannya sebagai perkara nasib.

Prinsip pemikiran dan aspirasi perubahan yang kritis ini dirumuskan dalam perbincangannya yang mendalam tentang perjuangan pembaharuan dan kebebasan akliah dan ijtihad dalam tradisi Islam dan signifikasinya dalam pandangan intelek dan ijtihad yang dikembangkannya. Menurutnya, ijtihād sentiasa merangkul upaya untuk menzahirkan pembacaan teks yang kritis ketika ia terbuka kepada interpretasi dan penafsiran, atau ketika teks tidak menangani hal dan keadaan yang tertentu, atau ketika konteks harus diambil kira dalam menerapkan teks, walaupun ketika teks kelihatan telah muktamad dan qat'i (eksplisit). Keabsahan dan keperluan terhadap pembacaan yang kritis seperti ini jarang dipersoalkan, kecuali tentunya oleh mereka yang menuruti tren pemahaman literalis yang sempit.

Hubungan dialektik antara teks dan konteks menuntut akal manusia untuk mencari jalan beriltizam melalui dua paduan daripada tahap pengetahuan, iaitu yang berlandaskan prinsip yang kekal berhubung dengan praktis ibadah dan akhlak dan yang berkait dengan realiti kehidupan yang sentiasa berubah dalam masyarakat manusia.

Pada asasnya, idea dan prinsip pemikiran yang kritis ini dilakarkan Tariq Ramadan dalam bukunya What I Believe yang menggariskan manhaj dan prinsip asas yang dibangunkannya yang menekankan keperluan terhadap ijtihād dan nalar dalam melanjutkan agenda reformasi. "Berhubung dengan rujukan Islam pendekatan saya sentiasa untuk membangunkan tema dalam tiga langkah yang berbeza. Pertama, saya mengutip sumber: di sini ialah ayat atau hadith Nabi (saw) dan ini ialah makna literal. Kedua, saya menghuraikan bacaan yang berbeza yang ditawarkan ulama dalam aliran sejarah dan juga kemungkinan yang wujud untuk menginterpretasi ayat atau hadith tersebut, kerana perumusannya atau berdasarkan pesan Islam. Ketiga bermula dari ayat (atau hadith) dan pelbagai tafsirannya yang mungkin, saya mencadangkan pemahaman dan interpretasi yang mengambil kira konteks di mana kita hidup. Itulah yang saya panggil pendekatan reformis." 29

\section{MASYARAKAT MUSLIM DI EROPAH}

Dalam perspektifnya tentang Muslim di Eropah, Tariq Ramadan telah melantarkan faham pembaharuan yang konstruktif dengan menganjurkan kepada penyertaan dalam kehidupan di Barat sambil mempertahankan identiti dan nilai agama yang hakiki. Interpretasi baru tentang fiqh al-aqalliyyat (jurisprudence of Muslim minorities) ini telah menarik ramai kelompok muda untuk memakai fatwa dan tafsiran Islamnya yang relevan dengan kehidupan di Eropah sambil mempertahankan idealisme dan keyakinan mereka yang sejati: "that Tariq Ramadan uses ijtihad, or the concept of analyzing sacred Islamic texts in light of present-day circumstances, to allow for and advocate assimilation into the youths' Western society while being able to practice Islam. In doing so, Ramadan's interpretation of Islam frees the faith from the cultural and ethnic practices and traditions often presented to youths as 'Islamic' or as being justified by Islam. By encouraging youths to read sacred texts and analyze their place in society today, Ramadan empowers youths and propagates individual piety rather than a blind-faith mass following." 30

Idea kebebasan dan liberalisme politiknya ini mempunyai keabsahan dalam struktur pemerintahan moden seperti dipertahankan oleh Andrew F. March di mana pandangannya tentang kerakyatan Eropah dan kerjasama sosial adalah sebahagian besarnya "munasabah" dari sudut pandang liberalisme politik. 31

Ramadan menangani sebahagian isuisu yang fundamental ini dalam bukunya To Be

${ }^{29}$ Ibid, h. 3.

${ }^{30}$ Haina Karim, "Jihad of the Youth: Why First Generation Immigrant Muslim Youths are Drawn to the Philosophy of Tariq Ramadan" (Unpublished M.A. Thesis, Faculty of The School of Continuing Studies and of The Graduate School of Arts and Sciences, Georgetown University, Washington, D.C., 2009), h. i.

31 March, Andrew F. "Reading Tariq Ramadan: Political Liberalism, Islam and 'Overlapping Consensus'." Ethics \& International Affairs, Vol. 21, No. 4 (Winter 2007): pp. 399-413. 
A European Muslim (Menjadi Muslim Eropah), dari kenyataan yang lahir dari Muslim yang menetap Eropah pada masa ini. Berlandaskan kepada kajian yang teliti terhadap sumbersumber Islam, ia cuba untuk menjawab persoalan asas tentang integrasi sosial, politik, budaya dan hukum bagi umat Islam Eropah. Beliau menunjukkan bahawa ianya mungkin untuk hidup sebagai Muslim dalam negara bangsa Eropah yang pluralistik, pelbagaiagama, yang membicarakan tentang identiti Muslim yang sentiasa terbuka, sentiasa inklusif, sentiasa bergerak Pandangan ini diuraikan dengan konkrit dalam pengenalan Radical Reform:

"In To Be A European Muslim, I presented a
new reflection based on the main classical
instruments offered by the fundamentals of law
and jurisprudence (usül al-fiqh): critical and
autonomous interpretative reasoning (ijtibäd),
the public interest and common good
(maslahab), and detailed fatäwä. This
approach was meant to enable European (and
Western) Muslims to respond to the issues and
challenges of their presence in secularized
societies where religious reference plays a
secondary role in public life." 32

Isu yang dibangkitkan ini menarik perhatian luas khalayaknya di Barat, yang tertarik dengan kaidah dan visinya yang instruktif, sebagaimana dizahirkan oleh Alan Wolfe dalam The Chronicle of Higher Education yang menyimpulkan bahawa pesan Ramadan yang paling penting - saranannya kepada umat Islam di Barat untuk menjadikan Barat rumah mereka - adalah satu yang rakyat Amerika harus terutamanya raikan. Ini diperkuat dalam reviu oleh Le Monde Diplomatique yang dengannya Ramadan telah mulai melakarkan jalan kepada reformasi dan perubahan dalam pemahaman tentang Islam dalam masyarakat Muslim di Barat.

Dalam bukunya yang berpengaruh Western Muslims and the Future of Islam, Ramadan menangani persoalan tentang apakah maknanya menjadi Muslim Barat - yang semakin penting dalam hubungannya dengan masa depan kedua-duanya Islam dan Barat.

32 Tariq Ramadan, Radical Reform: Islamic Ethics and Liberation, hh. 1-2.
Sementara media menfokuskan kepada Islam radikal, Ramadan mengklaim, revolusi yang senyap sedang melanda komuniti Islam di Barat, ketika umat Islam dengan aktif mencari jalan untuk hidup secara harmoni dengan agama mereka dalam konteks Barat. Umat Islam di Perancis, Inggeris, German dan Amerika - wanita serta lelaki - membentuk semula acuan agama mereka dalam rupa yang setia kepada prinsip Islam, berpakaian dalam budaya Eropah dan Amerika, dan secara definitif berakar dalam masyarakat Barat. Tujuan Ramadan adalah untuk menciptakan Barat Islam yang mandiri, yang diikatkan tidak dalam tradisi negara-negara Islam tetapi dalam realiti budaya di Barat.

Beliau bermula dengan menawarkan pembacaan yang baru terhadap sumbersumber Islam, menafsirkannya bagi konteks Barat dan memperlihatkan bagaimana pemahaman yang baru tentang prinsip Islam yang universal dapat membuka pintu kepada integrasi dalam masyarakat Barat. Beliau kemudian menun-jukkan bagaimana prinsip ini dapat diterapkan dalam rangka yang praktis. Ramadan berhujah bahawa umat Islam dapat malah wajib - berpegang kepada prinsip mereka sementara terlibat sepenuhnya dalam kehidupan sivik dalam masyarakat sekular di Barat. Ia menawarkan visi yang mengesankan tentang identiti Muslim yang baru, yang menolak sekaligus idea bahawa Islam harus ditakrifkan dalam pertentangan dengan Barat refleksi yang dilakarkan dalam pengenalannya kepada Radical Reform:

"Western Muslims and the Future of Islam
took up this reflection with a more direct
approach to the issue of the sciences and
methodologies at the source: the second part of
the book took the form of practical, concrete
proposals in such fields as spirituality,
education, social and political commitment,
interfaith dialogue, and so on. Those two
works (Western Muslims and the Future of
Islam and To Be A European Muslim)
popularized a thought and methodology that
spread well beyond what I hoped for." 33

33 Tariq Ramadan, Radical Reform: Islamic Ethics and Liberation, h. 2. 
Sementara dalam bukunya Western

Muslims: From Integration to Contribution, Ramadan menekankan keperluan pada penyertaan dan sumbangan yang konkrit dari Muslim dan untuk menjadi rakan dalam masyarakat demokratik di Eropah: "for those who were born in the West or who are citizens, it is no longer a question of "settlement" or "integration" but rather of "participation" and "contribution" 34 (bagi kalangan yang lahir di Barat atau adalah warganya, persoalannya tidak lagi berkisar tentang "penempatan" atau "integrasi" tetapi sebaliknya adalah "penyertaan" dan "sumbangan")

Ringkasnya ia mengajukan peranan bagi Muslim Eropah dan membawakan paradigma yang baru dalam pemikiran dan penglibatan sivik. Politik 'integrasi' dibincangkan dan peta laluan yang dinamik bagi sumbangan yang positif dijelaskan, yang menyerlahkan anjakan paradigma mental yang diperlukan untuk membuatkan sumbangan ini bermakna. Politis dalam reviunya melukiskan sikap yang krusial ini: "Filasuf Muslim Tariq Ramadan mengajak kita untuk mengikutnya dalam refleksi yang kompleks dan mendalam [Western Muslims] adalah buku bagi setiap orang yang sanggup untuk berfikir."

Kekuatan pengaruh Islam, menurutnya telah mengakar dan pantas berkembang di Barat, di mana: "a constructive, in-depth movement is under way and Islam has become a Western religion. Western Islam is a reality, just like African, Arab, or Asian Islam" 35 (pergerakan yang konstruktif, mendalam sedang berjalan dan Islam telah menjadi agama Barat. Islam Barat adalah realiti, sebagaimana Islam Afrika, Arab atau Asia)

Pada asasnya, tema yang kritikal ini telah dirumuskan dengan berkesan dalam bukunya What I Believe dalam bab "Multiple Identities: First an American (a European, an Australian), or a Muslim", "Western Muslim: Religion and Culture", "The Sense of Belonging and the "Post-Integration" Approach", "The West and Its Mirror: A New "We", dan dalam Appendix II: Manifesto for a New "We". Dengan menekankan tentang fikah Muslim di Eropah dan visi masa depan

\footnotetext{
34 Tariq Ramadan, What I Believe, hh. 5-6.

35 Ibid, h. 85.
}

Islam yang integral di Barat. Ini dilakarkan dalam Lampiran II dari bukunya What I Believe: Manifesto for a New "We" An Appeal to Western Muslims and Their Fellow Citizens", dengan menggariskan nilai persefahaman dan fikrah pembaharuan dan fiqh aqalliyyat ini: "jutaan umat Islam kenyataannya, telah membuktikan setiap hari bahawa "integrasi agama" adalah kenyataan yang telah dicapai, bahawa mereka sesungguhnya senang terlingkung di negara Barat yang citarasa, budaya dan jiwanya telah menjadi milik dan kepunyaan mereka." 36

Pada dasarnya, beliau menyeru kepada integrasi budaya dan semangat toleransi dan dialog dan menegaskan tanggungjawab untuk mengembangkan tradisi dan nilai Islam yang demokratik dan faham keterbukaan dan aspirasinya yang moden yang krusial bagi perkembangan Islam di Barat:

"Apa yang kita panggil Islam Barat adalab persis sama sifatnya: ia adalab Islam yang menghormati kepercayaan, amalan dan prinsip-prinsip umum dan menjadikan berbagai kebudayaan Barat dan Eropah sebagai kebudayaannya sendiri. Kita memperhatikan labirnya kebudayaan Islam Barat di dalam mana kaum Muslim kekeal berpaut pada prinsip agama yang fundamental sementara sepenubnya memiliki kebudayaan Barat mereka. Mereka adalah keduanya Muslim pada agamanya dan Barat yang mumpuni pada kebudayaannya, dan itu tidak menjadi masalah sama sekali." ${ }_{77}$

Dasar ini digarap dengan konkrit dan substantif yang memungkinkan nilai Islam berkembang dan faham kemanusiaan yang ideal ditegakkan. Mengungkapkan tentang dirinya beliau menzahirkan ciri-ciri keperibadian yang beragam yang menghadam aspirasi budaya dan kemanusiaan yang integral ini: "Saya telah lama mengulangi kepada umat Islam dan kepada rakan senegara saya bahawa saya adalah seorang Swiss dari segi kerakyatan, Mesir dari segi kenang-kenangan, Muslim pada agama, keEropahan dari segi budaya, universal dari segi prinsip, Maghribi dan Mauritania dari segi adopsi” 38 dan

\footnotetext{
${ }^{36}$ Ibid, h. 125.

${ }^{37}$ Ibid, h. 42.

38 Tariq Ramadan, What I Believe, h. 38.
} 
"berdasarkan pada pemulihan yang diperlukan ini, kaum Muslimin dapat menunjukkan, secara logik dan tanpa polemik, bahawa mereka berkongsi intisari daripada nilai di atas mana Eropah dan Barat bersandar dan bahawa tradisi agama mereka sendiri juga telah menyumbang kepada kebangkitan dan pengembangan nilai-nilai ini." 39

\section{KESIMPULAN}

Sebagai pelopor pembaharuan Islam abad ini, Tariq Ramadan telah membawa aspirasi perubahan yang signifikan melalui reformasi pemikiran yang kental dan radikal. Perjuangan-nya ini telah membawa pengaruhnya yang fenomenal di dunia Islam dalam upaya pencerahan dan nahdah di abad ke 21. Pengaruhnya yang luar biasa dan peranan yang dimainkannya dalam mengangkat nilai perubahan ini telah diiktiraf oleh Majalah Time dengan menamakannya antara 100 pembaharu terpenting di abad ke21 (One of the Time Magazine's 100 most important innovators for the $21^{\text {st }}$ century). Karya dan penulisannya membawa aspirasi kebangkitan dalam memperjuangkan ide perubahan (tajdid) dan cita-cita reform yang kritikal. Dalam merealisasikan hasrat ini ia merangkul idealisme dan faham Islam yang dinamik, inklusif, plural dan universal. Aspirasi yang diketengahkannya menjadi pemangkin kepada upaya pencerahan yang instrumental di mana "karya-karya Tariq Ramadan akan mengambil tempatnya dalam tawarikh pemikiran Islam" sebagai diramalkan oleh akhbar Perancis Le Monde Diplomatique.]

${ }^{39}$ Ibid, h. 84.

\section{DAFTAR PUSTAKA}

Musa, Ahmad Farouk. "Reformasi Radikal dan Tariq Ramadan" (Radical Reform and Tariq Ramadan). Diakses 23 Ogos, 2010. http://irfront.net/post/articles/articlesmalay/reformasi-radikal-dan-tariqramadan/

Musa, Ahmad Farouk. "Keperluan pada Wacana yang Tenang tentang Etika Islam." (Need for Critical Calm Discourse on Islamic Ethics). Ucapan Pembukaan Majlis Hi-Tea bersama Tariq Ramadan "Memikirkan Semula Reformasi Islam" di Hotel Renaissance, Kuala Lumpur. 14 Julai, 2012.

Rahmat, Ahmad Fuad. "An Interview with Tariq Ramadan.” (Temubual dengan Tariq Ramadan) Diakses pada Ogos 3, 2012.

http://irfront.net/post/interviews/aninterview-with-tariq-ramadan/

Adnan, Ahmad Muziru Idham. "Reformasi ke arah Perubahan Transformasi: Ulasan buku Radical Reform: Islamic Ethics and Liberation oleh Tariq Ramadan". Diakses pada 27 Jun, 2016). http://irfront.net/post/articles/reformas i-ke-arah-perubahan-transformasi-ulasanbuku-radical-reform-islamic-ethics-andliberation-oleh-tariq-ramadan-bahagian-i/

Fourest, Caroline. Brother Tariq: The Doublespeak of Tariq Ramadan. New York: Encounter Books, 2008.

Edward W. Said. Representations of the Intellectual: The 1993 Reith Lectures. New York: Vintage Books, 1994.

Karim, Haina. "Jihad of the Youth: Why First Generation Immigrant Muslim Youths are Drawn to the Philosophy of Tariq Ramadan" (Unpublished M.A. Thesis, Faculty of The School of Continuing Studies and of The Graduate School of Arts and Sciences, Georgetown University, Washington, D.C., 2009).

Hamka. Tafsir al-Azhar, 10 jil. Singapura: Pustaka Nasional, 1982.

March, Andrew F. "Reading Tariq Ramadan: Political Liberalism, Islam and 
'Overlapping Consensus'.' Ethics \& International Affairs, Vol. 21, No. 4 (Winter 2007): pp. 399-413.

Akyol, Mustafa. (April 3, 2014). Islam perlukan John Locke-nya (Islam needs its John Locke). Diakses pada April 3, 2014. http://irfront.net/post/articles/islamperlukan-john-locke-nya/

Nong, Nor Faridah Mat. Identiti Muslim Eropah: Perspektif Tariq Ramadan Kuala Lumpur: Institut Terjemahan \& Buku Malaysia (ITBM), 2014.

Donnelly, Paul. Tariq Ramadan: The Muslim Martin Luther? Diakses pada Feb 16, 2002. http://www.salon.com/2002/02/15/ra madan_2/

Ramadan, Tariq. Muslim in France: The Way Towards Coexistence. UK: Islamic Foundation, 1999.

Ramadan, Tariq. Western Muslims and the Future of Islam. New York: Oxford University Press, 2004.

Ramadan, Tariq. In the Footsteps of the Prophet: Lessons from the Life of Mubammad. New York: Oxford University Press, 2007.

Ramadan, Tariq. Muhammad (saw) Rasul Zaman Kita, terj. R. Cecep Lukman Yasin. Jakarta: Serambi, 2007.

Ramadan, Tariq. Radical Reform: Islamic Ethics and Liberation. New York: Oxford University Press, 2009.

Ramadan, Tariq. The Quest for Meaning: Developing a Philosophy of Pluralism. Penguin Global, 2010.

Ramadan, Tariq. What I Believe. New York: Oxford University Press, 2010.

Ramadan, Tariq. Western Muslims: From Integration to Contribution. UK: Awakening Publications, 2012.

Ramadan, Tariq. The Arab Awakening: Islam dan the New Middle East. New York: Oxford University Press, c2012.

Ramadan, Tariq. "Islam, Democracy \& Human Rights: The Awakening of the Muslim World" Penang in Asia Lecture III. Pinang Ballroom, Traders Hotel, Penang (17 Julai 2012).

Ramadan, Tariq. "A Civil State: Ideas and Challenges, A Lecture by Prof Tariq Ramadan.” (Negara Madani: Ide dan Cabaran, Syarahan oleh Tariq Ramadan). Anjuran Yayasan Islam Pulau Pinang,
Evergreen Laurel Hotel, Gurney Drive, Penang (18 Julai 2012).

Ramadan, Tariq. "Respect Beyond Tolerance." Diakses pada September 17, 2013. http://tariqramadan.com/english/respec t-beyond-tolerance/

Ramadan, Tariq. "Strength in Pluralism." (Kekuatan dalam Pluralisme). Gulf News. Diakses pada July 23, 2012. http://gulfnews.com/opinion/thinkers/s trength-in-pluralism

Ramadan, Tariq. To Be A European Muslim. UK: The Islamic Foundation, 2015.

Ramadan, Tariq. Islam. UK: Penguin Books, 2017.

Koya, Zakiah. "Tariq Ramadan: On Respect, Thinking and Dialogue." (Tariq Ramadan tentang hormat, nalar dan dialog). Diakses pada Jan 14, 2010. http://www.alahkam.net/home/content/tariqramadan-respect-thinking-and-dialogue 